\title{
Informatics for secondary education - the UNESCO/IFIP curriculum as a resource for developed and developing countries
}

\author{
Tom van Weert \\ School of Informatics, Faculty of Mathematics and \\ Informatics, University of Nijmegen \\ P. O. Box 9010, 6500 GL Nijmegen, The Netherlands \\ Tele + 3124 3652084; Fax + 31243653450 \\ E-mail:tomvw@cs.kun.nl
}

\begin{abstract}
Countries currently beginning to use Informatics and Information and Communication Technology (ICT) in any major way should be able to benefit from the newest technological developments. Fundamental concepts and results of Informatics are independent of any computer platform or software environment. A cadre of professionals with a sound informatics background must be developed and supported. Advantage can be gained by capacity building through international cooperation, by using the similarity in the diversity of earlier experiences elsewhere and by concentrating on stable concepts. The UNESCO/IFIP secondary informatics curriculum - adaptable to specific cultural, educational and technological environments - can be implemented by countries and communities for the education of both computer literate and Informatics professionals at the secondary education level. But also elementary school materials, as well as materials for preservice and in-service training of teachers, and for the preparation of teacher trainers can be based on the curriculum.
\end{abstract}

Keywords

Developing countries, informatics, infrastructure, secondary education

Capacity Building for IT in Education in Developing Countries

G. Marshall \& M. Ruohonen (Eds.)

(C) 1998 IFIP. Published by Chapman \& Hall 


\section{INTRODUCTION}

\section{Taking advantage of international cooperation}

With respect to Africa Fatima Seye-Sylla concludes in Education and Informatics Worldwide (1992) that computers are still expensive for developing countries but Africa cannot remain indifferent to the technological revolution. To follow, one by one, the steps of the developed countries would, however, be the best way to remain the slave to the tool, rather than its master. She questions whether Africa should deny itself the efficiency of computers and their profits in use, because it is poor. Since Africa is poor in natural resources, she thinks that the best way to improve the economy is to develop and use human resources. The African Region may be poor but objectives can be achieved if the political will exists. As SeyeSylla says: 'If African countries want to develop the human resources through education, which is a factor of sustainable economic and social development, they will have to put their maximum efforts together to achieve this goal'.

That concern about technology and development is supported by the International Federation for Information Processing Working Group on Secondary Education (IFIP WG 3.1). In this group international specialists work together; individual members are appointed by peers, not by national governments, on the basis of their expertise. Human resource development, both of its members and others, is the key in the work of IFIP Working Groups.

Informatics is a science dealing with theory, methods and techniques. Methods and techniques from informatics are the basis of the development of informatics technology: word processors, information systems, technical systems and other components. Informatics technology is often combined with other technologies; the resulting combination is often called Information Technology (IT) or Information and Communication Technology (ICT).

IFIP WG 3.1 members share their growing expertise not only with each other, but with other agencies, organisations and countries as the Information Revolution accelerates. IFIP's work has an international orientation and is based on international experience at the 'state of the art' level. On the one hand, this experience shows that there is not just one best solution to problems related to informatics and information technology in education. Solutions depend on local circumstances. On the other hand, this experience makes it possible to predict developments and identify needed processes of change. For these reasons nonmembers are able to benefit from the IFIP WG 3.1 experience and move forward more quickly by avoiding costly, but non-essential steps in development. With this in mind IFIP WG 3.1 has developed a set of Guidelines of Good Practice (Ruíz i Tarrago, 1993; Taylor, Aiken and van Weert, 1992) and the UNESCO/IFIP secondary curriculum on informatics (Tinsley and van Weert, 1994).

\section{Taking advantage of similarity in diversity}

There are important economical, social and cultural differences between countries, but also important similarities. Take the introduction of Information Technology into education as an example. All industrialised countries and quite a few developing countries have tackled this problem in much the same way - 'Computer Literacy' for all. While approaches may differ from one country to the other and 
while the content of educational materials may differ, the problems encountered turn out to be much the same. IFIP members identified common problems and suggested solutions in Guidelines of Good Practice. The development of the Guidelines showed that similarities exist notwithstanding local differences and that the identification of common problems provided a basis for practical international cooperation. But in each case an application of theory in good practice must take into account local circumstances.

\section{Taking advantage of earlier experiences}

Some people argue that when starting late, you have to go through the same development processes as the early starters. This is not IFIP's view. Starting late you can take advantage of early experiences; you may go through the same stages of development, but you will be able to go a lot faster, and cheaper, because you know where you are going. Starting late one should leap to the forefront of development, aim at 'state of the art' policies and practices as well as emerging trends, and bypass obsolete ideas and technology. This leap is possible if based on the fundamental concepts and results of Informatics which are independent of any specific hardware or software environments.

\section{Taking advantage of stable concepts}

Multiple changes, quantitative and qualitative, have occurred in computer and software technology. Technological knowledge may rapidly and easily become obsolete. At the same time fundamental concepts and results of Informatics are as independent of any specific computer platform and software environments as ever. Capacity building should therefore be based on stable concepts and not on the technology of today - which may be antiquated by tomorrow. To take part in the newest developments countries currently beginning to use Informatics and Information and Communication Technology in any major way should build up a cadre of professionals with a sound Informatics background.

\section{CRITICAL ASPECTS OF CAPACITY BUILDING}

\section{The need for Informatics education}

There is a clear need for Informatics and Information and Communication Technology in secondary education. Data in Table 1 show the need for qualified personnel in developed countries and give a clear demonstration of the need for effective Informatics learning at all levels

The need for professionals skilled in ICT operations and application of informatics concepts will, in most countries, far exceed current levels. Secondary education has an important role to play in closing the gap. 
Table 1 Need for training

Year

1970

2000

Professionals with

ICT qualification

$5 \%$

$65 \%$

Professionals in other

disciplines with Informatics

qualifications

$1.5 \%$

$20 \%$

Professional

informaticians

$0.5 \%$

$4 \%$

Schul Computer Jahrbuch, 1993 (p. 15)

\section{Different phases of Informatics development}

To get a grip on the very fast developments of Informatics, these may be grouped into three phases:

- automation: information technology is used to automate simple, standard processes, such as business accounting;

- information: software tools support the professional at the work place, empowering the individual. Information Technology is used as an umbrella term for these tools;

- communication: powerful personal computers are integrated in local area, wide area and global networks as personal (and sometimes) intelligent communication agents. Information and Communication Technology is used as an umbrella term in this situation.

Countries or communities will find themselves in one of these phases of Informatics development.

\section{Different levels of technological and human resource development}

The different phases of Informatics development are paralleled by different levels in technological and human resource development:

- automation: essential infrastructures are still being developed. Informatics is the sole responsibility of technical personnel;

- information: personal use of computing tools grows, with a strong influence of the user on the adaptation of systems; 
- communication: computer use is characterised by collaboration between users, and Informatics and Information Technology form part of the essential infrastructure of the organisation, institution or country.

In secondary education the Informatics curriculum in its implementation must aim at the appropriate level of technological and human resource development in countries or communities.

\section{Required competencies are changing}

Technological developments have resulted in changes in work and the organisation of work. This is very apparent in countries which have passed through the information and communication phases of Informatics development. As the changes occur, required competencies, which secondary education has to provide, change. In the information, and especially in the communication phases, inductive thinking, generalist informatics competencies enabling expert work, decision-making, handling of dynamic situations, teamwork and communication competencies become increasingly important.

To take part in the newest developments countries currently starting to invest heavily in Informatics and ICT must take account of the changes in required competencies. Their secondary Informatics curriculum should contribute to the building up of a reservoir of professionals with the required competencies.

\section{THE ROLE OF INFORMATICS IN SECONDARY EDUCATION}

Learning to use and become proficient with ICT are basic necessities in secondary education. Currently, in developing or developed countries, the ability to use ICT is a necessity, as has been illustrated by the need for ICT competent professionals shown in the Schul Computer Jahrbuch study (1993).

Everyday use of ICT cuts across all aspects of economical and social life and across all disciplines in secondary education so ICT should be integrated in all disciplines of secondary education.

Where does this leave the discipline of Informatics? Technological developments in ICT are very rapid. This creates two problems. First of all, technological knowledge quickly becomes obsolete and new technology has to be frequently mastered. To allow a smooth adaptation to new technology and intelligent use of current ICT, secondary education should offer its students an understanding of ICT based on invariant, stable concepts. Since ICT is built on the foundation of Informatics, understanding Informatics concepts is indispensable.

Secondly, countries need to educate students who can immediately obtain employment in ICT-supported companies. In economic life tools of ICT have to be developed, sometimes from scratch, but most of the time by adaptation of existing tools (software packages). Students must learn the basics of development and adaptation, which in turn are based on concepts, methods and techniques of Informatics.

Finally secondary schools must teach Informatics to prepare their students for further education. 


\section{Implications for an Informatics curriculum for schools}

Current and future needs should be reflected in an Informatics curriculum for secondary education, both in developing and developed countries. This curriculum should address:

- computer literacy - the competent use of basic ICT tools;

- the competent use of special, problem- or subject-oriented ICT tools;

- problem solving with Informatics - application of methods and techniques of Informatics to problems in other subject areas;

- solving professional problems with Informatics - application-oriented Informatics, aimed at application of methods and techniques of Informatics to business or industry problems.

The use of ICT should be integrated in any discipline in secondary education where the student must have access to the same personal computer support as professionals in business and industry find on their desks (Ruíz i Tarrago, 1993). Like the professional, students must use the personal tools in an integrative way. Informatics aims to solve problems in an increasingly more complex world. Special purpose conceptual 'programming' environments in which microworlds of reality can be modeled and problems from this microworld solved provide a setting for working on complex problems. Everyday examples of this type of conceptual programming are the building of macros for text processing and the building of formulas in spreadsheets. More advanced examples are the creation of simulation models in simulation software tools and problem solving in mathematical tools such as Maple and Mathematica.

The backbone of ICT and conceptual programming is Application Oriented Informatics. It includes modeling methods and techniques, design of conceptual data structures and program design in high level as well as conceptual programming languages. As 'Informatics for a few' it may be offered in preparation of specific jobs or specialised further studies. It may also include more advanced topics such as software engineering and design of human computer interfaces.

\section{THE UNESCO/IFIP CURRICULUM FOR SCHOOLS}

The UNESCO/IFIP Secondary Informatics Curriculum has been designed to reflect the competencies required for today and tomorrow , and allows adaptation to local circumstances by school book authors and publishers. Table 2 provides an overview of the curriculum.

The curriculum is built from units which are grouped in modules designed for different educational levels - Foundation level modules and Advanced modules. Depending on local circumstances these units, designed for one level, may also be used at another level. 
Table 2 An overview of the UNESCO/IFIP curriculum

Secondary education Level Topics

$\begin{array}{lll}\text { General education } & \text { Foundation } & \begin{array}{l}\text { A. Computer literacy } \\ \text { B. Application of ICT tools in other } \\ \text { subject areas } \\ \text { C. Informatics in other subject areas } \\ \text { (optional) }\end{array} \\ \text { General education } & \text { Advanced } & \begin{array}{l}\text { B. Application of ICT tools in other } \\ \text { subject areas } \\ \text { C. Informatics in other subject areas }\end{array} \\ \text { Vocational education } & \text { Advanced } & \text { D. Informatics in professional areas }\end{array}$

In the curriculum the units are described according to: Objective and subobjectives, context, content, description of student activities, resources needed and optional resources, links to other units, and teaching methodology.

\section{Topic A. Computer literacy}

Objectives - Handle basic software and hardware facilities of a computer; apply application oriented software tools (spreadsheet, database, etc.); solve routine problems in algorithmic form (e.g., by building macros); social, economical and ethical consequences.

Modules and units - the units covering this topic can be found in the Core Module, the Core Elective Module, the General Options Module and the Optional Programming Module as shown in Table 3 
Table 3 Computer Literacy

\begin{tabular}{|c|c|c|c|}
\hline $\begin{array}{l}\text { Core } \\
\text { Module }\end{array}$ & $\begin{array}{l}\text { Core Elective } \\
\text { Module }\end{array}$ & $\begin{array}{l}\text { General Options } \\
\text { Module }\end{array}$ & $\begin{array}{l}\text { Optional Programming } \\
\text { Module }\end{array}$ \\
\hline Hardware & $\begin{array}{l}\text { Database } \\
\text { design and } \\
\text { use }\end{array}$ & $\begin{array}{l}\text { Keyboarding } \\
\text { skills }\end{array}$ & $\begin{array}{l}\text { Introduction to } \\
\text { programming }\end{array}$ \\
\hline $\begin{array}{l}\text { Systems } \\
\text { software }\end{array}$ & $\begin{array}{l}\text { Spreadsheet } \\
\text { design and use }\end{array}$ & $\begin{array}{l}\text { Desktop } \\
\text { publishing }\end{array}$ & $\begin{array}{l}\text { Top-down programming } \\
\text { design }\end{array}$ \\
\hline $\begin{array}{l}\text { Computing } \\
\text { trends }\end{array}$ & $\begin{array}{l}\text { Careers in } \\
\text { Informatics }\end{array}$ & \multicolumn{2}{|l|}{ Communication } \\
\hline $\begin{array}{l}\text { Using a } \\
\text { computer }\end{array}$ & & \multicolumn{2}{|l|}{ Creating graphics } \\
\hline Text processing & & \multicolumn{2}{|c|}{ Working with multimedia } \\
\hline $\begin{array}{l}\text { Working with a } \\
\text { database }\end{array}$ & & \multicolumn{2}{|c|}{ Computer-aided design } \\
\hline Graphics & & \multicolumn{2}{|c|}{ Modelling/simulation } \\
\hline $\begin{array}{l}\text { Social and ethical } \\
\text { issues }\end{array}$ & & \multicolumn{2}{|l|}{ Expert systems } \\
\hline Choice of tools & & \multicolumn{2}{|l|}{$\begin{array}{l}\text { Robots } \\
\text { Music } \\
\text { Statistics }\end{array}$} \\
\hline
\end{tabular}

Topic B. Use of ICT tools in other subject areas

Informatics and Information and Communication Technology tools may be of considerable value in teaching many subjects at Foundation and Advanced levels. By integrating the use of computers within subject areas, most of the computer literacy objectives can be met without the need for a separate computer literacy course. UNESCO/IFIP's curriculum offers examples of integrated computer use in Natural Sciences, Mathematics, Languages, Social Sciences, Art and Music.

Objective - students should be able to use ICT tools to solve problems in other subject areas. Units which contribute to the integrated teaching of computer use are for the most part found in the Core Elective Module and the General Options Module as shown in Table 4. 
Table 4 Use of ICT tools in other subject areas

\begin{tabular}{lll}
\hline $\begin{array}{l}\text { Core Elective } \\
\text { Module }\end{array}$ & $\begin{array}{l}\text { General Options } \\
\text { Module }\end{array}$ & $\begin{array}{l}\text { Optional Programming } \\
\text { Module }\end{array}$ \\
\hline $\begin{array}{l}\text { Database design } \\
\text { and use }\end{array}$ & Keyboarding skills & $\begin{array}{l}\text { Introduction to } \\
\text { programming }\end{array}$ \\
$\begin{array}{l}\text { Spreadsheet } \\
\text { design and use }\end{array}$ & Desktop publishing & $\begin{array}{l}\text { Top-down programming } \\
\text { design }\end{array}$ \\
Core Module & Communication & \\
Text processing & Creating graphics & \\
Working with & Working with multimedia \\
a database & Computer-aided design & \\
Working with graphics & Modelling/simulation \\
Choice of tools & $\begin{array}{l}\text { Expert systems } \\
\text { Robots } \\
\text { Music } \\
\text { Statistics }\end{array}$ & \\
\hline
\end{tabular}

\section{Topic C. Informatics in other subject areas}

In this module, shown in Table 5, relatively complex problems will be solved with the help of methods and techniques of informatics. These problems are either solved using general purpose, high level programming environments or using special-purpose, conceptual 'programming' environments in which microworlds of reality can be modelled and problems from this microworld solved. Everyday examples of this type of conceptual programming are: the building of macros for text processing and the building of formula in spreadsheets. More advanced examples are the creation of simulation models in simulation software tools by clicking and dragging, and problem solving in mathematical tools such as Maple and Mathematica.

Objective - students should be able to methodically model and solve relatively complex problems in other subject areas.

Prerequisite - Topic B. Use of ICT tools in other subject areas 
Modules and units - units which contribute to the solving of problems in other subject areas using informatics are found in the Core Elective Module, the Programming Module and the General Advanced Module as shown in Table 5.

Table 5 Informatics in other subject areas

$\begin{array}{lll}\text { Core Elective } & \text { Programming } & \text { General Advanced } \\ \text { Module } & \text { Module } & \text { Module }\end{array}$

$\begin{array}{ll}\text { Database design } & \text { Introduction to } \\ \text { and use } & \text { programming }\end{array}$

Spreadsheet design and use
Top-down

programming design
Foundations of programming and software development

Advanced elements of programming

\section{Applications of modeling}

\section{Topic D. Informatics in professional areas}

The topic presented in this module, shown in Table 6 , is relatively simple professional problems to be solved with the help of methods and techniques of Informatics. The problems are solved using methods and techniques of Informatics which are in professional use.

Objectives - students should be able to methodically plan, design, realise and implement relatively simple application systems with the aid of problem oriented software tools and identify problems involved in project management.

Prerequisites are Topic B. Use of ICT tools in other subject areas, Units P1 and P2 from the Optional Programming Module

Modules and units which contribute to the solving of problems in professional areas using Informatics are found in the Vocational Advanced Module.

Table 6 Informatics in the professional areas

Vocational Advanced Module

Business Information systems

Process control systems
Students methodically plan, design, realize and implement relatively simple information systems with problem-oriented tools

Students methodically plan, design, realize and implement relatively simple process control systems with problem-oriented tools 
Project management

Students deal with variables influencing progress and success, and plan team activities for small projects.

\section{5}

\section{IMPLEMENTATION OF THE CURRICULUM}

How can this curriculum be implemented, especially in developing countries? The experience, gained in both developed and developing countries, of the members of the working party which has designed the curriculum, shows that implementation is dependent on different stages of technological and human resource development in any community or country, and in the secondary education systems of those communities and countries. In their experience the following stages can be discerned:

Stage 1: insufficient hardware, few experienced teachers; Stage 2: more hardware, teachers receive some in-service training;

Stage 3: more hardware, a larger percent of teachers receive training and some achieve degrees in computer science;

Stage 4: sufficient hardware, almost all teachers are computer literate and many achieve degrees in computer science.

The technological and human resources in each stage define boundary conditions for the implementation of the curriculum. From the IFIP/UNESCO curriculum those parts can be selected by education authorities which can be realised under the boundary conditions at the appropriate level of education. When the boundary conditions change, new parts of the curriculum can be implemented. In such a way implementation is possible quickly and at a minimum cost. Other experiences, for example gained in Russia (van Weert, 1996), have shown such an approach to be viable.

In stage one, when there is insufficient hardware and few experienced teachers, it is advised to start implementation of the curriculum at the Advanced General level (ages 16-19) with Computer Literacy core units for most students and core elective units as an extra for a selection of students.

In stage two, when there is more hardware and teachers receive some in-service training, it is advised to move the Computer Literacy core units to the Foundation of General Education (ages 12-16) for all students, to extend the core elective units to all students at the Advanced General Education level, to offer most students at this level Computer Literacy option modules and to offer selected students optional programming units. In this stage optional programming units may also be offered to students in Advanced Vocational Education.

An overview of which units to choose for implementation at which educational level in which phase is given in Table 7.

Table 7 refers to units which come from the Core Module (units C1-C10), the Core Elective Module (units E -E3), the General Options Module (units Op1Op11), the Optional Programming Module (units P1-P2), the General Advanced Module (units GA1-GA3) and the Vocational Advanced Module (units VA1-VA3). 
Table 7 Phases in development

\begin{tabular}{|c|c|c|c|c|}
\hline $\begin{array}{l}\text { Phases } \\
\text { in development }\end{array}$ & Initial & Second & Third & Advanced \\
\hline
\end{tabular}

Educational

level

General

Education

Foundation

Ages 12 -16

\begin{tabular}{|c|c|c|}
\hline $\begin{array}{l}\text { all students: } \\
\text { literacy core } \\
\text { units } C 1-C 10\end{array}$ & $\begin{array}{l}\text { all students: } \\
\text { literacy core } \\
\text { units } C 1-C 10\end{array}$ & $\begin{array}{l}\text { all students: } \\
\text { literacy core } \\
\text { units } C 1-C 10\end{array}$ \\
\hline & $\begin{array}{l}\text { all students } \\
\text { Electives E1-E3 }\end{array}$ & $\begin{array}{l}\text { all students } \\
\text { Electives E1-E3 }\end{array}$ \\
\hline
\end{tabular}

$\begin{array}{ll}\begin{array}{l}\text { General } \\ \text { Education } \\ \text { Advanced }\end{array} & \begin{array}{l}\text { most } \\ \text { students: } \\ \text { literacy } \\ \text { core }\end{array} \\ \text { Ages 16-19 } & \text { selected all students: } \\ & \begin{array}{l}\text { students: electives } \\ \text { electives E1-E3 } \\ \text { E1-E3 }\end{array}\end{array}$

selected

students:

optional

programming

\begin{tabular}{|c|c|c|}
\hline $\begin{array}{l}\text { most students: } \\
\text { options Op1- } \\
\text { Op1 1 }\end{array}$ & $\begin{array}{l}\text { all students: } \\
\text { options Op 1- } \\
\text { Op11 }\end{array}$ & $\begin{array}{l}\text { most students } \\
\text { option Op1- } \\
\text { Op11 }\end{array}$ \\
\hline $\begin{array}{l}\text { selected } \\
\text { students: }\end{array}$ & $\begin{array}{l}\text { selected } \\
\text { students: }\end{array}$ & $\begin{array}{l}\text { selected } \\
\text { students: }\end{array}$ \\
\hline $\begin{array}{l}\text { optional } \\
\text { programming } \\
\text { P1-P2 }\end{array}$ & $\begin{array}{l}\text { optional } \\
\text { programming } \\
\text { P1-P2 }\end{array}$ & $\begin{array}{l}\text { optional } \\
\text { programming } \\
\text { GA1-GA3 }\end{array}$ \\
\hline
\end{tabular}

Vocational
extra
for
vocational
students:

extra

for

vocational

vocational

students:

for

vocational

students: 


$\begin{array}{lll}\text { optional } & \text { optional } & \text { optional } \\ \text { programming } & \text { programming } & \text { programming } \\ \text { P1-P2 } & \text { P1-P2 } & \text { P1-P2 }\end{array}$

vocational

students:

vocational

vocational

advanced units

VA1-VA3

Obtaining copies of the UNESCO/IFIP curriculum for schools

The curriculum is available, free of charge, through your regional UNESCO office or through the UNESCO headquarters in Paris. The curriculum has been developed in English but through the efforts of many Informatics professionals translations in French, Spanish, Russian, Chinese, Japanese, Polish and, lately, Portuguese are available. The website address $<\mathrm{http}$ ://www.ge-dip-etat-ge.ch/cip/unesco/ frwelcome.html $>$ gives access to the English and French translations of the curriculum.

\section{Addresses}

Adresses of regional UNESCO offices can be found on the World Wide Web: $<$ http://www.education.unesco.org/unesco/educsect/offices.html $>$

UNESCO Headquarters

7, Place de Fontenoy

H. G. 435

75352 Paris 07 SP

France
UNESCO office Harare

P. O. Box

Highlands, Harare

Zimbabwe

\section{Acknowledgment}

The UNESCO/IFIP Informatics curriculum for secondary education was prepared by a working party of the International Federation for Information Processing Working Group on Secondary Education (WG 3.1):

Ulrich Bosler, Germany Charles Duchateau, Belgium

Sam Gumbo, Zimbabwe Raymond Morel, Switzerland

Harriet Taylor, USA Peter Waker, South Africa

Zoraini Wati Abas, Malaysia

Chair \& Joint Editor: Tom van Weert, Netherlands

Joint Editor: David Tinsley, United Kingdom 


\section{REFERENCES}

Ruíz i Tarrago, F.R. (1993) Integration of Information Technology in Secondary Education: Main Issues and Perspectives, in Guidelines for Good Practice, (ed. T.J. van Weert), IFIP Working Group 3.1, Geneva, 7-15.

Seye-Sylla, F. (1992) Current restraints and prospects: Regional examples, in Education and Informatics Worldwide, The State of the Art and Beyond. (eds. Hebenstreit J., et. al.), Jessica Kingsley Publishers/UNESCO, London, 196202.

Schul Computer Jahrbuch (1993), Ausgabe '93/94, Metzler Schulbuch Verlag, Stuttgart, 15.

Taylor, H.G., Aiken, R. M., van Weert, T.J. (1992) Informatics Education in Secondary Schools, in Guidelines for Good Practice (ed. T.J. van Weert), IFIP Working Group 3.1, International Federation for Information, Geneva.

Tinsley, J.D. and van Weert, T.J. (eds.) (1994) Informatics for secondary education, a curriculum for schools, UNESCO, Paris. The curriculum may be obtained free of charge through regional UNESCO offices.

van Weert, T.J. (1996) Analysis of UNESCO/IFIP documents, published by UNESCO in 1994-1995, in: Proceedings of the Second UNESCO Congress on Education and Informatics, in press.

Tom J. van Weert is Director of the School of Informatics (Computer Science) of the Faculty of Mathematics and Informatics of the University of Nijmegen, Netherlands. The School of Informatics educates Masters in Informatics and also provides informatics courses for other departments. Tom van Weert also teaches the management of large software projects to Informatics students who develop real software applications in multidisciplinary teams. Previously he worked in teacher education teaching Mathematics and Informatics and prior to that as a computer system engineer in an academic environment. His background is in applied mathematics. He has been active in several IFIP Working Groups and is currently Chair of IFIP Working Group 3.2 on university education. 